Journal of

Applied

Linguistics
JAL (PRINT) ISSN 1479-7887

JAL (ONLINE) ISSN 1743-1743

Research note

\title{
Research on transnational Yucatec Maya-speakers negotiating multilingual California
}

\author{
Anne Whiteside
}

\begin{abstract}
This project combined methodologies from linguistic anthropology, participatory action research and interactional sociolinguistics. Data was collected from participant observation, four case studies, extensive interviews and a language and literacy survey. Multilingual conversations were recorded and analyzed with Conversation Analysis, with a focus on actions and identities as they emerge through enacted stance. The analysis was informed by concepts taken from the anthropology and sociology of transnationalism. The study shows four Maya-speaking individuals negotiating highly multilingual social worlds, where English, when it appears, is more often lingua franca than dominant code, and where participants use their various languages strategically and contingently to accomplish their various goals. These choices are constrained by their status as workers at the bottom rung of a social field characterized by undocumented status and the persistence of colonial discourses. Recommendations for research and practice based on research findings include: (i) reconsideration of second language pedagogies for such immigrant populations (ii) the use of stance in the analysis of multilingual conversations (iii) more research on undocumented status and how it contributes to the silencing of minority language populations and (iv) the use of participatory research methods in studies of undocumented and indigenous communities.
\end{abstract}

KEYWORDS: MULTILINGUALISM, TRANSNATIONALISM, CONVERSATION ANALYSIS, STANCE, SOCIOLINGUISTICS, IDENTITIES, INDIGENOUS MEXICANS, YUCATEC MAYA, MIGRATION, CONVERSATION ANALYSIS, DISCOURSES OF COLONIALISM

\footnotetext{
Affiliation

City College of San Francisco, Mission Campus, 1045 Valencia St., San Francisco, CA 94110, USA. email:awhitesi@ccsf.edu
} 


\section{Subject and aims of the research}

This doctoral research looks at the language practices of recent migrants from Yucatan, Mexico living in San Francisco, California, and their relative use of their three languages: Maya (an indigenous language), Spanish (the colonial language) and English (a global language). San Francisco, like many postindustrial cities, increasingly depends on immigrant labor; some 112 languages are spoken in the Bay Area (Hendricks 2003). In the polyglot restaurants where many Yucatecans work, English is a lingua franca and local models of English are scarcely represented. Although they may successfully navigate this sea of accents and varieties, about half of Maya-speaking adults have four years of formal schooling or less (INEGI 2000), leaving them ill-prepared for academic English language programs.

The present study aims to inform language pedagogy by documenting the linguistic resourcefulness of this group, by challenging language programs to build on learners' capacities rather than on shaky academic foundations. Addressing a need for research on multilingual conversations in out-of-school contexts, the study integrates ethnographic observations of social, cultural and linguistic practices with micro analyses of recorded conversations. The findings are relevant to contexts where colonial and neo-colonial hierarchies of language play out locally. The study includes a language and literacy survey which used a participatory approach, in part to overcome mistrust of outside researchers. The survey was designed to collect data useful to community activists and agencies serving this population, who are currently applying its findings. The survey project demonstrates how participatory research can work effectively in communities resistant to documentation.

The study subjects are among an estimated 50-80,000 Yucatecan immigrants in California, some 10,000 of whom live in San Francisco (F. Molina Ortiz Monasterio, email to author, 14 September 2006; Hendricks 2003). Many small towns in Yucatan have lost half their populations to migration to the U.S., as local economies in rural Mexico become increasingly unsustainable. On both sides of the border, Maya-speakers face economic, social, and cultural marginalization, including racist attitudes and discrimination from other Mexicans and from dominant U.S. society (Fox and Rivera-Salgado 2004: 4; Kearny 1994). Like three quarters of Mexicans in the U.S. less than five years (Passel 2005: 16), many of Yucatecan immigrants are also undocumented.

The U.S. economy thrives on undocumented labor: two out of five low wage workers are immigrants without papers (Capps, Fix, Passel, et al. 2003: 1). Their 'illegitimate' status compromises participation in public domains in ways documented by Chavez (1992) and others. Because Yucatec migration is a recent phenomenon, Maya is marked as an outsider language, and by

\section{equinoxonline}


implication, linked to dubious legal status, like other indigenous Mexican and Central American languages (Haviland 1989). The informants in this study were all undocumented; one was warned before he crossed the U.S. border: 'You better not speak like that (i.e. in Maya) up there or they'll know you're not from there'. In a global economy that increasingly recruits such immigrants, it seems critical that applied linguists address the impact of legal status on language practices, and this study proposes to begin such a discussion.

\section{Theoretical and methodological approaches}

The study takes a sociolinguistic approach, following Heller's (1992, 1995) seminal work on language choice and symbolic domination and Rampton's $(1995,2005)$ emphasis on complex and layered repertoires. The micro analysis is grounded in interactional sociolinguistics, underscoring the position that intersubjectivity is an interactional achievement. Recent work in Conversation Analyses of L2 conversations helped shift the focus away from L2 error and repairs, showing instead what L2 interactions do accomplish (Gardner and Wagner 2004). Conversation Analysis frequently fails, however, to consider how the larger context contributes meaning to interpretive procedures (Duranti 2001; Fairclough 1989; Levinson 1983). Against this backdrop, the present study borrows concepts from linguistic anthropology (Hanks 1996) and language socialization (Ochs 2002, 1996, 1993; Garrett and Baquedano-Lopez 2002; Baquedano-Lopez 2001) which are related to the enactment of actions and identities, interpreted through reference to practices and norms gained through participant observation. Two basic questions guided this research:

1) How are Maya-speakers using their languages across a variety of social spaces?

2) How are people using their various languages to manage actions and identities?

For immigration-related analysis, the study turned to frameworks from the sociology and anthropology of transnationalism, in particular from Appadurai (2001) Sassen $(1998,1995)$ on global trends, and from Fox and Rivera-Salgado (2004), Kearny (1991, 1995, 1998), Chavez (1992) and Rouse (1991) on migration from Mexico. This literature reframes the discussions of 'acculturation' in terms of transnational practices which transcend localities, as migrants participate simultaneously in two worlds. The study also looks at 'modes of incorporation', and structural and relational 'embeddedness' of ethnic enclaves, using Portes' (1995) discussion of the economic structure of social relations between immigrants and the 'receiving' society. 


\section{The research process}

Qualitative data was collected between fall 2003 and fall 2005 from interviews, case studies and participant observation, in homes, shops, beauty parlors, restaurants, apartments, clinics and schools, and at events such as fiestas, baptisms and funerals. These were examined for 'emic' perspectives on language practices. Thirteen service professionals working with this population were interviewed for 'etic' perspectives (Duranti 1997: 270). Four focal informants were followed extensively and interviewed individually: a woman in her 50s, living in the U.S. for 14 years with her spouse and daughter, and three men ages 28,48 and 50, living in the U.S. for less than 5 years, one with extended family, and two in apartments crowded with up to 17 roommates. Multilingual interactions between these four and speakers of other languages were recorded at work in stores, clinics, schools and homes. Follow-up interviews to get participants' perspectives on 'what's going on' in their recorded conversations were planned, but hectic lives and greater priorities intervened in three of the four cases. Situations where legal status was salient were too unpredictable and fraught with risk, making recording problematic; data on such situations came from stories and observation. Recorded data was analyzed using Conversation Analysis techniques and was triangulated with supplementary data from the interviews and field-notes.

Quantitative data on patterns of language use were collected through the language and literacy survey, which was collaboratively designed and administered by a team of six Maya-speaking community college students and the researcher. The survey used Community Based Participatory Research (CBPR) approach, developed by public health researchers with a record of success in 'hidden' populations (Minkler and Wallerstein 2003). CBPR treats research itself as social practice, emphasizing research which contributes to the wellbeing of its subjects (Park 2003). It argues for shared control over purpose and goals of the research, its design, and the uses of its findings (Minkler and Wallerstein 2003; Lewis 2001). CBPR proved highly effective: 170 adults were surveyed in Maya and Spanish. The sample is non-probabilistic: with no census data, there was no sampling frame, random sampling was not feasible, snowball sampling failed as network members became unwilling to participate; the team resorted to a mix of haphazard and target sampling.

\section{Outcomes and interpretations}

What emerges from this broad range of data is a rich and layered picture of language contact, 'crossing', mixing and learning. The case studies indicate a high degree of language contact at work and in neighborhoods: at the worksites

\section{equinoxonline}


of two informants there were 14 language groups represented; Maya-speaking kitchen crews in these restaurants often used Maya to build team spirit and to complain about working conditions. The informants engaged in extensive 'translocal' practices - i.e., practices that transcend distance and local boundaries (Appadurai 2001). They make frequent and extended telephone calls home, share videotapes of hometown fiestas, use on-line journals, and run into fellow townspeople in their San Francisco neighbourhood. Field notes documented a constant flow of people, goods and ideas; circular stays, businesses that follow clients - even evil spirits which can migrate in seconds. Learning English is an investment not just for work in the U.S. but for jobs in the tourist industry in Yucatan, or to teach future migrants.

Survey data also suggest that use of English at work was limited for this sample. Half of respondents mention use of some English, but only 7\% use English alone; a third use Maya, and over 90\%, Spanish. Over three quarters of the respondents, including some who declared Spanish their L1, used Maya at home and in neighborhoods, alone or in combination with Spanish. Answers on language proficiency suggest linguistic insecurity in a third of respondents who depend on Spanish and/or Maya, who rate their fluency regular (OK, so-so); 69\% rate their English poor or non-existent. This is unsurprising since a majority $(70 \%)$ were recent arrivals with five years or less in the U.S. The (non-statistical) survey sample $(\mathrm{N}=170)$ was predominantly male $(84 \%)$, under $25(36 \%)$ or between $26-45$ years old $(58 \%)$.

Ethnographic data suggest such linguistic insecurity may be related to discriminatory practices and few years of schooling, combined with ideas about a lost pure, or 'hach' Maya (Pfeiler 1996). People claim that colonial attitudes persist, contributing to a habitus of silence. Those who are undocumented also learn to keep quiet, as the symbolic violence (Bourdieu 1991) of their 'illegitimate' status erodes their right to speak. As one informant noted, 'You feel like you shouldn't be talking or drawing attention to yourself'. Another says, 'we can't talk...against those, against the bosses or tell them, 'I want a raise'... They know that there are lots of illegals here, so the boss takes advantage'. The study was limited by lack of data on situations where legal status is foregrounded, and recommends more research at immigration hearings, in detention centers and at the border, as Haviland (1989) Kearney (1998), and De Fina (2003) have done.

The recorded data show even those with limited L3 resources are adept at accomplishing legitimate actions and identities, despite their limited linguistic resources in English. One key informant, Don Francisco, who runs a restaurant out of his apartment, uses his preferred customer status with local merchants to get them to use Spanish and Maya with him. In the following exchange with a Vietnamese grocer who calls himself ‘Juan', Don Francisco (DF) succeeds

\section{equinoxonline}


in getting Juan to 'perform' a few words of Maya to show the researcher the influence he has had on the neighbourhood.

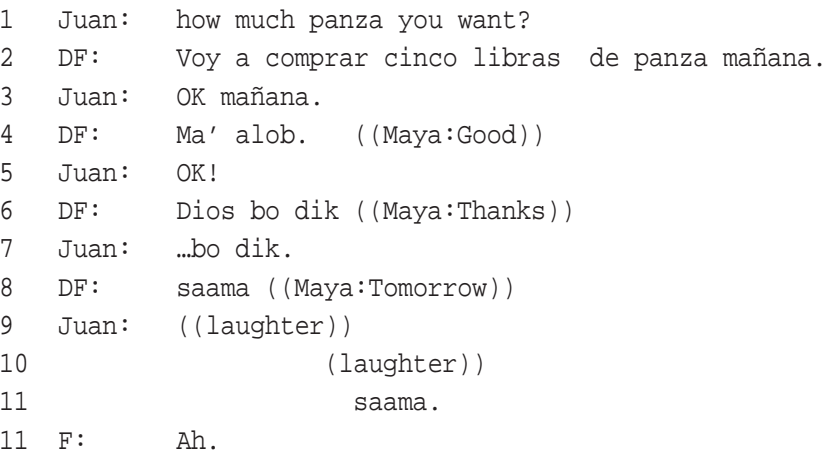

Although Juan answers DF in English in \#5, DF persists with Maya in \#6, and continues in Maya in the next pair (\#8 and 9). Juan's affective stance suggests this is not preferred, but he complies anyway.

A second key informant taped himself in conversation with his Anglo American roommate. The informant is called 'John Smith', a pseudonym he decided on for himself in the study 'so they think it's a gringo chewing up English'. Throughout the conversation, John Smith ignores Roommate's crude references to 'extinct Maya' 'dead language' and 'primitive' Indians in loincloths; both manage to maintain the intersubjectivity, despite John Smith's English errors. In the following excerpt, John Smith (JS) impresses on his roommate (Rmt) that in Mexico, Mayans are rebels:

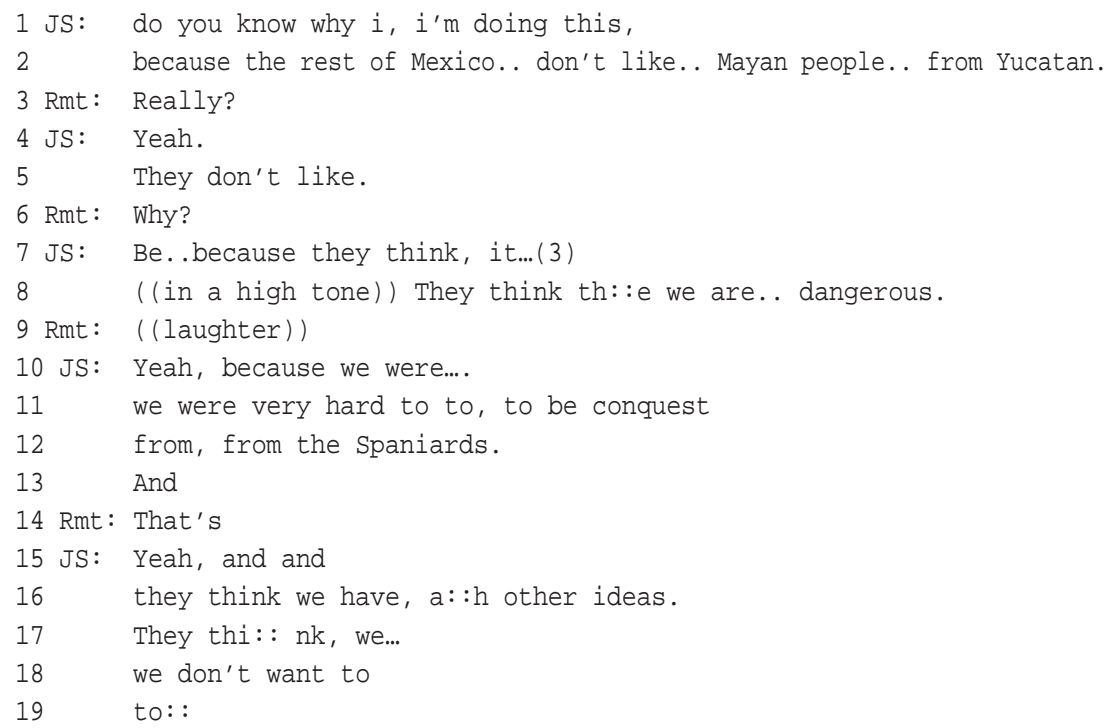




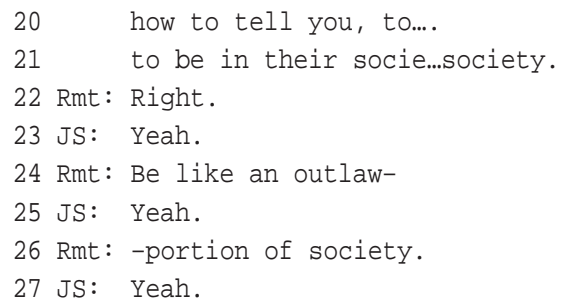

By aligning himself with 'dangerous' rebels in \#8, JS wins Rmt's approval, signalled by Rmt's laughter in \#9, and his 'right' in \#22. JS establishes this positive identity despite Rmt's many references to racialized stereotypes. In a follow up interview JS interpreted Rmt's references as based on a belief in white superiority. JS also explained that he made no attempt to correct him because 'A person in that camp isn't capable of understanding what you understand', adding, 'I'm a person who doesn't like to talk too much'. He agrees many Mayaspeakers share this feeling. Following Jaworski (1993) this 'failure to mention' can be seen as a common response to symbolic violence, in this case, in the discourses of colonialism.

\section{Conclusions}

By combining research methodologies, the researcher was able to draw on a wide range of contextual findings in the analysis of conversational data. In the above examples we see Don Francisco leveraging his status in the local 'enclave' economy to get Juan to speak Maya (Portes 1995), and John Smith using silence in ways deeply rooted in Yucatecan history. By focusing on stance, actions and identities, the analyses reveal how much may be accomplished in multilingual conversations despite the limited linguistic repertoires of its participants. More research is needed on stance in multilingual conversations. The research also suggests that the undocumented status, economic marginalization and the symbolic violence of colonial discourse all contribute to the avoidance of the use of Maya and the strategic use of silence. Given the high proportion of undocumented migrants in the world, the relationship between undocumented status on the right to speak of immigrants should be a research priority for applied linguists interested in language and power.

\section{About the author}

Anne Whiteside teaches at City College of San Francisco. Her areas of study are early first and second language literacy, informal second language acquisition, cognitive linguistics, and transnationalism. She and Claire Kramsch co-authored a paper for the Modern Language Journal (Kramsch and Whiteside 2007), and

\section{eøuinoxonline}


another for Applied Linguistics (forthcoming). Her chapter, entitled “ "We don't speak Maya, Spanish or English": Yucatec Maya-speaking transnationals in California, and the social construction of competence' will be included in a anthology edited by Neriko Doerr on the Native Speaker Revisited.

\section{Notes}

1 This study wouldn't have been possible without the inspiration and great support of Claire Kramsch, my four informants, and the terrific researchers from El Pueblo Maya en City College of San Francisco, who some day will step out of the shadows and publish their own research.

2 Transcription conventions:

elapsed time by tenth of seconds

(.) micropause

? raised intonation

full stop marks falling intonation double parentheses contain transcriber's comments

$:::$ prolongation of immediately prior sound

\section{References}

Appadurai, A. (2001) Globalization. Durham NC: Duke University Press.

Baquedano-Lopez, P. (2001) Creating social identities through doctrina narratives. In A. Duranti (ed.) Linguistic Anthropology: a reader 343-58. Oxford: Blackwell.

Bourdieu, P. (1991) Language and Symbolic Power (G. Raymond and M. Adamson Trans.) Cambridge, MA: Harvard University Press.

Capps, R., Fix, M. E., Passel, J. S., Ost, J., \& Perez-Lopez, D. (2003). A Profile of the Low-wage Immigrant Workforce: Brief \#4. The Urban Institute. Retrieved Nov. 12, 2005 , from http://www.urban.org/UploadedPDF/310880_lowwage_immig_wkfc.pdf

Chavez, L. R. (1992) Shadowed Lives: undocumented immigrants in American society. New York: Harcourt Brace.

De Fina, A. (2003) Identity in Narrative: a study of immigrant discourse. Philadelphia: John Benjamins.

Duranti, A. (ed.) (2001) Linguistic Anthropology: a reader. London: Blackwell.

Duranti, A. (1997). Linguistic Anthropology. Cambridge: Cambridge University Press.

Fairclough, N. (1989). Language and Power. New York: Longman.

Fox, J. and Rivera-Salgado, G. (eds) (2004) Indigenous Mexican Migrants in the United States. La Jolla: Center for U.S.-Mexican Studies and Center for Comparative Immigration Studies, University of California San Diego.

\section{eøuinoxonline}


Gardner, R. and Wagner, J. (eds) (2004) Second Language Conversations. New York: Continuum.

Garrett, P. and Baquedano-Lopez, P. (2002) Language socialization: reproduction and continuity, transformation and change. Annual Review of Anthropology 31: 339-61.

Hanks, W. F. (1996) Language and Communicative Practices. Boulder Co: Westview Press.

Haviland, J.B. (1989) What words did the defendant say in your presence? Mixtecs, migrants, multilingualism, and murder. Working Papers and Proceedings for the Center for Psychosocial Studies. Chicago. Retrieved on 17 November 2007 from http://www. anthro.ucsd.edu/\%7Ejhaviland/Publications/MixtecsMigrants.pdf

Heller, M. (1992) The politics of codeswitching and language choice. Journal of Mulilingual and Multicultural Development 13: 123-42.

Heller, M. (1995) Language choice, social institutions and symbolic domination. Language and Society 24: 373-405.

Hendricks, T. (2003, November 25). From southern Mexico to Northern California: As numbers grow, immigrants from Yucatan getting higher profile. San Francisco Chronicle.

Instituto Nacional de Estadística Geografía e Informática (INEGI). (2000) Censo general de población y vivienda. Retrieved on 12 November 2005 from http://www.inegi.gob. $\mathrm{mx} /$ inegi/default.asp

Jaworski, A. (1993) The Power of Silence. (Vol. 1) London: Sage.

Kearney, M. (1991) Borders and boundaries of state and self at the end of empire. Journal of Historical Sociology 4: 52-74.

Kearney, M. (1994). Desde el indigenismo a los derechos humanos: Etnicidad y política mas allá de la mixteca. Nueva Antropología, 14(46), 49-67.

Kearney, M. (1995) The local and the global: anthropology of globalization and transnationalism. Annual Review of Anthropology 24: 547-65.

Kearney, M. (1998). Transnationalism in California and Mexico at the end of empire. In T. M. Wilson \& H. Donnan (eds), Border Identities (pp. 117-142): Cambridge University Press.

Kramsch, C. \& Whiteside, A. (2007) Three fundamental concepts in SLA and their relevance in multilingual contexts . Modern Language Journal, Focus issue 91: 907-922.

Levinson, S. (1983) Pragmatics. Cambridge: Cambridge University Press.

Lewis, H. M. (2001) Participatory Research and Education for Social Change: Highlander Research and Education Center. In P. Reason \& H. Bradbury (eds), Handbook of Action Research (pp. 356-362). Thousand Oaks: Sage.

Minkler, M. and Wallerstein, N. (eds) (2003) Community-based Participatory Research for Health. San Francisco: Jossey-Bass.

Ochs, E. (1993) Constructing social identity: a language socialization perspective. Research on Language and Social Interaction 26: 287-306.

Ochs, E. (1996) Linguistic resources for socializing humanity. In J. Gumperz and S. Levinson (eds) Rethinking Linguistic Relativity 407-37. Cambridge: Cambridge University Press.

\section{eøuinoxonline}


Ochs, E. (2002) Becoming a speaker of culture. In C. Kramsch (ed.) Language Acquisition and Language Socialization: ecological perspectives 99-120. New York: Continuum.

Park, P. (2003) Knowledge and participatory research. In P. Reason and H. Bradbury (eds) Handbook of Action Research: participative inquiry and practice 81-90. Thousand Oaks: Sage.

Passel, J. S. (2005) Unauthorized migrants: numbers and characteristics. Retrieved on 10 November 2005 from http://pewhispanic.org/reports/report.php?ReportID=46

Pfeiler, B. (1996). "Yan difereensia waye' yeetel maaya yukataan" (un estudio dialectal). In U. Hostetler (ed.), Los Mayas de Quintana Roo: Investigaciones antropologicas recientes (Vol. 14, pp. 7-13). Bern: Arbeitsblatter des Instituts fur Ethnologie der Universitat Vern.

Portes, A. (1995) The Economic Sociology of Immigration: essays on networks, ethnicity and entrepreneurship. NY: Russell Sage Foundation.

Rampton, B. (1995, 2005) Crossings: language and ethnicity among adolescents. London: Longman.

Rouse, R. (1991) Mexican migration and the social space of postmodernism. Diaspora 1 (Spring): 8-33.

Sassen, S. (1995) Immigration and local labor markets. In A. Portes (ed.) The Economic Sociology of Immigration 87-127. New York: Russell Sage Foundation.

Sassen, S. (1998) Globalization and its Discontents: essays on the new mobility of people and money. New York: The New Press.

Wilson T. M. and Hastings, D. (eds) (1999) Borders: frontiers of identity, nation and state. Oxford: Berg. 